\title{
Eco-mark on product packaging and its effect on the perception of quality
}

\begin{abstract}
The aim of the study was to investigate whether the eco-mark on the product packaging influences the perception of the product and the attractiveness of its packaging. In the first experiment, we tested three packaging designs (i.e. without eco-mark, with a standard Croatian eco-mark, with a redesigned eco-mark) using a rating scale for the measurement of perceived quality and a selection task for the measurement of participants' preferences. In the second experiment we manipulated the position of the eco-mark (i.e. in the center and in the corner) and tested its influence on the perceived quality and the attractiveness of the packaging. The results showed that the participants preferred packaging with the eco-mark, regardless of the variations in its design. The location of the eco-mark in the corner was better rated than in the center of the packaging, which indicates that people's perception of the packaging seems to be more influenced by the positon of the eco-mark than by its design characteristics.
\end{abstract}

\author{
Dorotea Kovačević (1) \\ Maja Brozović \\ Katarina Itrić Ivanda (1) \\ University of Zagreb, \\ Faculty of Graphic Arts, \\ Zagreb, Croatia \\ Corresponding author: \\ Dorotea Kovačević \\ e-mail: \\ dorotea.kovacevic@grf.hr
}

First recieved: 04.09.2019 Accepted: 08.10.2019.

\section{KEY WORDS}

Eco-mark, packaging, perceived quality, preferences, attractiveness

\section{Introduction}

Packaging contains a variety of visual information which enables it to communicate to consumers. Information provided on the packaging facilitates the consumers' ability to use the product better, but also to make judgments about the environmental aspects of the product. These ecological components can be presented through eco-labels. The main purpose of eco-labels is to identify consumer products which have reduced environmental impacts (Erskine \& Collins, 1997; Gertz, 2005) by conveying information about the environmental implications of the products (Ben Youssef \& Lahmandi-Ayed, 2008). Interestingly, the product-related messages that convey information about the environment may have greater scope than messages related to health (Hidalgo-Baz, Martos-Partal, \& González-Benito, 2017).

In general, people have positive reactions to products to which an eco-mark has been attached (Atkinson \&
Rosenthal, 2014; Faletar, Cerjak \& Kovačić, 2016). The presence of an eco-mark can have an impact on how potential buyers identify the level of product quality, especially food. Previous research has shown that the presence of an eco-mark may contribute to consumers' perception of a product, for example taste (Hemmerling et al., 2013). Moreover, it can influence consumers' behavior (Dočekalová \& Straková, 2011) and decision making (Drexler et al., 2018). For example, McEachern and Warnaby (2008) demonstrated how labels can play an important role in aiding purchase decisions. In their experiment, the majority of the participants expressed a purchase preference for food with a value-based label.

However, when it comes to consumer preferences, the label is not the only factor. Empirical evidence has showed that the packaging's visual appeal can also influence the perception of product quality (Delgado, Gómez-Rico \& Guinard, 2013; Magnier, Schoormans \& Mugge, 2016; Wang, 2013). 
According to these findings, both eco-labelling and the visual appeal of the packaging can have a significant impact on consumers' perception of the product. Our study aims to investigate the impact of the eco-mark in the case of a particular food product (tea) from two aspects. The first is testing the consumers' preferences regarding the presence of the eco-mark. The second is to investigate the effects of the eco-mark on the visual appeal of the packaging.

\section{Research questions}

Food products are the most commonly bought items for most people in everyday life. The perception of food product quality can vary across different packaging characteristics (Becker et al., 2011). For example, previous studies have shown that packaging color and shape can have an impact on people's perception of a product (Ares \& Deliza, 2010; Suzianti et al., 2015). Transparency of the packaging material can also be an influencing factor in evaluating product quality (Chandran, Batra \& Lawrence, 2009; Puyares, Ares \& Carrau, 2010), as well as type of visual information (Ares et al., 2010; Dantas et al., 2004). As noted earlier, the presence of an eco-sign on the packaging can also influence how people perceive product quality. In line with this, our first research question was do consumers prefer tea with an eco-mark more than tea without it? An additional related question was - are the preferences influenced by the design of the eco-mark?

Further research questions refer to the visual attractiveness of packaging with an eco-mark. According to the results of some previous studies, the visual appeal of the packaging can play an important role in forming the perception of product quality (Delgado et al., 2013; Magnier et al., 2016; Wang, 2013). It may affect buyers' choices (Reimann et al., 2010; Van der Laan et al., 2012) and influence buying intentions (Magnier \& Schoormans, 2015). Therefore, the secondary aim of this study was to investigate the effects of the eco-mark on the visual appeal of the packaging. In relation to this, our next research questions were: does the position of the eco-mark on the packaging affect the attractiveness of the packaging and does it play a role in the perception of quality?

\section{Methodology}

A two-part experiment was used to investigate the effects of the eco-mark on the participants' perception. In the first part, we wanted to get an insight into the influence of the presence of the eco-mark and its design on people's evaluation of the tea. In the second part, we aimed to compare the effects of the different positions of the eco-mark on the packaging attractiveness and the perception of quality.
The stimuli for the experiment were pictures of fictional tea packaging. Tea was selected since this type of product can be easily associated with ecological farming. Furthermore, tea was also selected in many previous studies oriented on packaging. For example, Vladić et al. studied the influence of tea packaging shape on people's perception (Vladić et al., 2016). Germelmann and Held (2014) investigated how images on tea packaging influence the formation of participants' expectations. De Godoy et al. (2013) have found the relationship between tea packaging and participants' satisfaction. Esmaeili, Henneberry and Ebneal (2013) have demonstrated that tea packaging and labelling can be an influencing factor on participants' hedonic valuation.

\section{Experiment 1}

\section{Participants}

Only those who stated that they had consumed tea regularly and care about environmental concerns were included in the study. There were 31 participants, 11 men and 20 women (age range 19-62; mean age 37 years). All participated voluntary.

\section{Samples}

Three pictures of the front packaging were used as stimuli (Figure 1). They varied according to the appearance of the eco-mark. The control packaging had no eco-mark. The other two packaging samples had an ecomark. One had a standard Croatian eco-mark, and the other one had a redesigned version of the eco-mark.

Figure 2 shows the standard eco-mark and our suggested redesigned version of it. The creation of the redesigned version was based on literature review. Several authors agreed on the importance of visual distinctiveness of the symbols (McDougall, de Bruijn \& Curry, 2000). People respond more quickly to distinctive icons (Fleetwood \& Byrne, 2006; Huang \& Chiu, 2007). The distinctiveness of the redesigned version of the eco-mark in our study was achieved by making a thicker edge weight of the frame, as suggested by Korpi and Ahonen-Rainio (2015). By enhancing the contrast between the symbol elements and the background, the distinctiveness was even more emphasized. Additionally, we made the symbol as concrete as possible according to Lehto's and Papastavrou's recommendations (1993). We added an illustration of a leaf which can be both simply presented and easily interpreted. Finally, we changed the typeface in order to evoke pleasant and "natural" impressions. According to previous typeface-related studies, it is advisable to use curvature typefaces ( $\mathrm{Li} \&$ Suen, 2010) in handwriting style in this case (Henderson, Giese \& Cote, 2004), so the design of the dominant textual part of the eco-mark was in line with this. 
WITHOUT

ECO-MARK

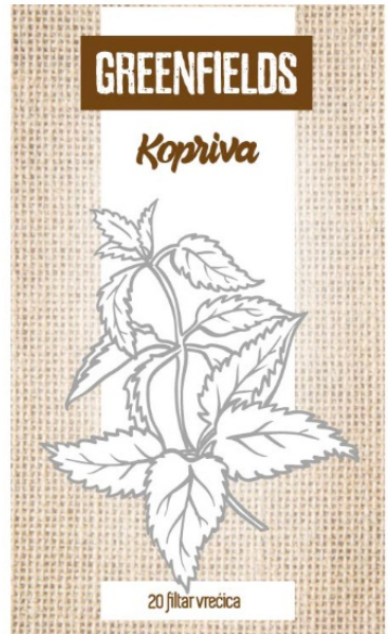

WITH STANDARD ECO-MARK

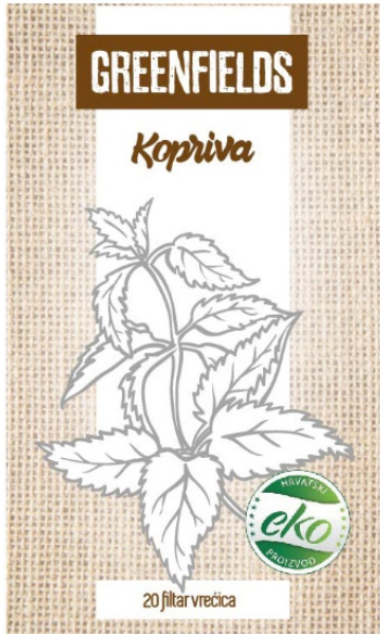

WITH

REDESIGNED ECO-MARK

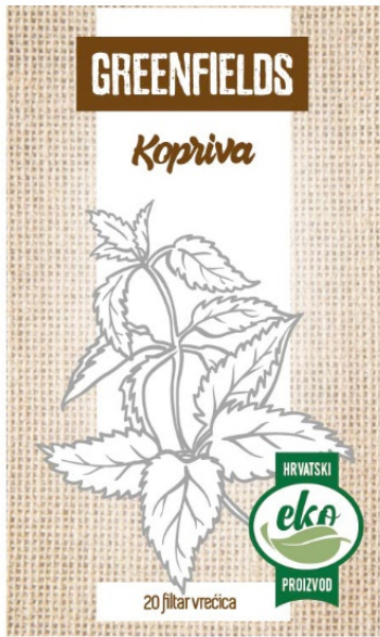

» Figure 1: The packaging samples used in the first experiment

The dimensions of the front packaging presented to the viewers were $70 \times 120 \mathrm{~mm}$. All of the packaging samples were designed using Adobe Photoshop CS6 software.
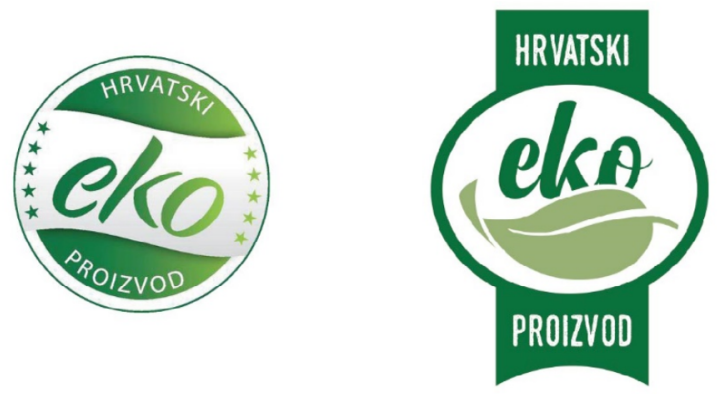

» Figure 2: The standard (left) and redesigned (right) version of the eco-mark used in the experiment

\section{Procedure}

The experiment was carried out in an experimental room where the participants approached individually. They were seated in front of a computer screen (Lenovo computer display LEN L1900pA). The resolution of the screen was $1280 \times 1024$ pixels.

The participants were asked to view each of the packaging samples and evaluate the quality of the tea, using a 7-point rating scale. The participants had to indicate the level of tea quality according to their personal opinion. They were encouraged to take as much time as they needed to observe all the elements on the packaging. The order in which the participants viewed the three packaging samples was counterbalanced. After the evaluation, the participants were asked to choose one of the packaging samples which they would select during their usual shopping activities.

\section{Dependent measures}

There were two dependent variables in the first experiment: perceived quality of the tea and preferences. The perceived quality of the tea was measured using a 7-point rating scale ranging from "unacceptable quality" to "high quality". The preferences were measured through the number of participants who selected each of the packaging samples in the selection task.

\section{Experiment 2}

\section{Participants}

There were 29 participants, 11 men and 18 women (age range 19-61; mean age 36.24 years). None of them participated in the previous experiment.

\section{Samples}

Packaging samples were similar to those from the first experiment. Two pictures of the packaging were used as stimuli (Figure 3). In this experiment, they varied according to position of the eco-mark. One packaging had the eco-mark located in the center of the packaging, which is considered to be more prominent, while another had the eco-mark in the bottom-right corner, considered to be less salient. The design of the eco-mark was taken from the first experiment- the redesigned version. 


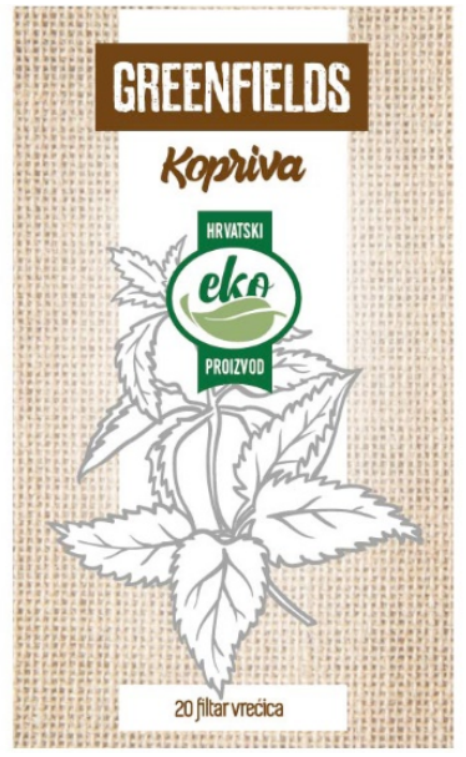

» Figure 3: The packaging samples used in the first experiment

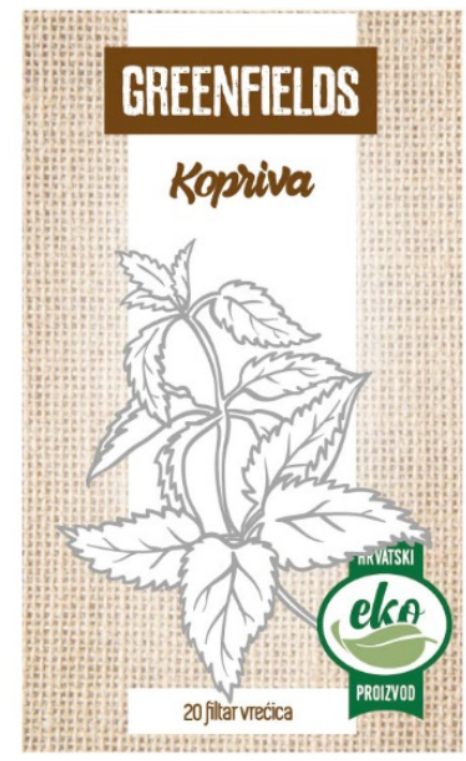

\section{Procedure}

The procedure was the same as described in Experiment 1. The participants were asked to view each of the two packaging samples and evaluate them without time limitation. In this experiment, they used a 7-point scale to rate not only the level of tea quality according to their personal opinion, but also the level of visual attractiveness of the packaging.

\section{Dependent measures}

There were two depended variables in this experiment: the perceived quality of the tea and the perceived attractiveness of the tea packaging. The perceived quality of the tea was measured using a 7-point rating scale ranging from "unacceptable quality" to "high quality". The perceived attractiveness was measured using a 7-point rating scale ranging from "unattractive" to "very attractive".

\section{Results}

\section{Experiment 1 - the influence of the presence of the eco-mark}

To examine whether the eco-mark influences the perception of the quality of the tea, a repeated measures analysis of variance was used. There was a significant effect of the presence of the eco-mark, $F(2,60)=13.54, p<0.001$. Additional post hoc analyses with Bonferroni correction showed no significant difference between the packaging with the redesigned and the standard eco-mark $\mathrm{t}(30)=$ $0.17, p=0.87$. In contrast, the results indicated that the quality was perceived as higher when the packaging was presented with the redesigned eco-mark ( $M=5.35$, SD $=1.31)$ than without the eco-mark ( $M=4.32, \mathrm{SD}=1.47)$, $\mathrm{t}(30)=-4.49, \mathrm{p}<0.001$. Also, the quality was perceived as better when the packaging was presented with the standard eco-mark ( $M=5.32, S D=1.33)$ than with no eco-mark ( $M=4.32, S D=1.47), t(30)=-3.94, p<0.001$.

The participants' frequencies of choices for each packaging sample are given in Table 1 . Cochran's $Q$ test showed a significant difference in participants' preferences regarding the eco-mark, $\chi^{2}(2)=8.00, p<0.05$. The additional comparisons done by McNemar's tests showed that there was no significant difference in participants' choices between the packaging with the redesigned (48\%) and the standard eco-mark (42\%), $p=0.85$ However, the control packaging was selected less frequently $(10 \%)$ than the packaging with the redesigned $(p<0.05)$ and the packaging with the standard eco-mark, $(p<0.05)$. This suggests that the packaging with both versions of the eco-mark were more preferred than the packaging without any eco-mark.

Table 1

Participants' choices of the packaging

\begin{tabular}{l|c|c}
\hline Packaging sample & N & \% \\
\hline Control (without eco-mark) & 3 & 10 \\
\hline With standard eco-mark & 13 & 42 \\
\hline With redesigned eco-mark & 15 & 48 \\
\hline
\end{tabular}




\section{Experiment 2 - the influence of the eco-mark position}

Paired t-tests showed that the position of the eco-mark had an impact on both the perceived quality and the attractiveness. The perceived quality was rated as higher when the eco-mark was positioned in the corner of the packaging $(\mathrm{M}=5.41, \mathrm{SD}=1.12)$ than in the center $(M=4.79, S D=1.01), t(28)=-2.84, p<0.05$. Similarly, the participants rated the attractiveness of the packaging better when the eco-mark was positioned in the corner $(M=5.03, S D=1.09)$ than in the center $(M=4.34$, $\mathrm{SD}=1.17), \mathrm{t}(28)=-3.18, \mathrm{p}<0.05$. Figure 4 illustrates these results.

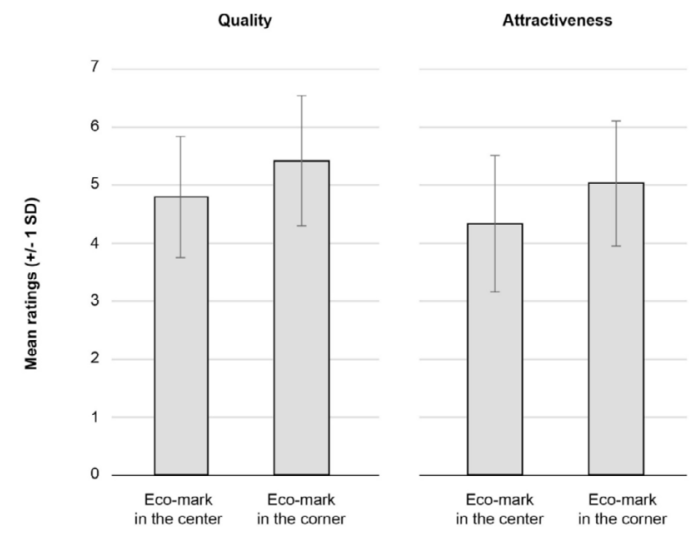

» Figure 4: Mean ratings for packaging with different positions of the eco-mark

\section{Discussion}

In this study, we examined the influence of the eco-mark on people's perception and preferences for tea packaging. The examination revealed that the participants perceived the quality of the tea differently depending on the presence of the eco-mark and its position.

Our first experiment showed that the tea in the packaging without any eco-mark was evaluated lower than the packaging with the eco-mark, regardless of the variations in its design. The result is in line with other previous studies which demonstrated the positive effect of eco-labelling on perceived quality (for example, Larceneux, Benoit-Moreau \& Renaudin, 2012). This is the case even when ecological cues refer not only to the product, but also to the packaging itself- its sustainability (Bratić, Miljković \& Gajdek, 2018; Magnier et al., 2016), eco-friendly design (Magnier \& Crié, 2015) and packaging environmental claims (Ertz, François \& Durif, 2017). Our finding is also supported by the studies which reported about the enhancement of taste perception of other food products with an organic label, such as yoghurt (Hemmerling et al., 2013), coffee (Sörqvist et al., 2013) and chips (Lee et al., 2013). Therefore, it may be that the perception of quality in our experiment was guided by the taste impressions that participants got in their everyday life, in which they associate the quality of food taste with organic origin.

The additional choice experiment showed consistent results in the participants buying preferences. Particularly, the eco-marked packaging was preferred over the one with no eco-label. This is in accordance with Drexler et al. (2018) who pointed out that organic product labeling can play a significant role in consumers' decision-making. What is more, people are willing to pay more for eco-labeled food (Banovic et al., 2019; Lee et al., 2013). However, a few previous studies showed that, in some cases, there is no effect of the organic label on consumers' purchase intentions (Loebnitz, Schuitema \& Grunert, 2015). In certain circumstances (i.e. isolated use of an environmental cue on non-food packaging) the eco-label can have a negative effect on consumers' perceptions and subsequent purchase intentions (Pancer, McShane \& Noseworthy, 2017). Thus, our findings cannot be generalized to all product categories. Also, when arguing about different effects of eco-labels on people's perception, the design of an eco-mark should be taken into consideration. In our study there was a greater proportion of participants who chose the packaging with the redesigned version of the eco-mark over its standard version. Although statistically insignificant, this result implies that graphic designers should create eco-marks with special care. The reason is twofold. Good graphic design of an eco-mark can have a positive impact on both attracting the attention of potential buyers (Taufique, Siwar \& Chamhuri, 2016) and the comprehension of the environmental-related information (Polonsky et al., 2002).

After the first experiment revealed that the presence of the eco-mark on the packaging has a positive influence on the participants' responses, our second experiment went further in the investigation of its other potential effects. We manipulated the position of the eco-mark (i.e. center vs. corner) in order to examine the influence on the participants' evaluations. Our results suggest that the eco-mark located in the less salient position (i.e. the low-right corner) indicates better tea quality and increases the attractiveness of the packaging. This may be explained by the fact that people are used to view the packaging design in which organic labels are the least centrally positioned elements (Orquin et al., 2019). Another reason could be the overlapping of the most informative element on the packaging (i.e. illustration) and the eco-mark located in the center. This caused visual clutter which probably led to an impression of bad design. The positive effect of positioning the design element on the right side of the packaging was also demonstrated in the study by Simmonds, Woods and Spence (2018). However, our results are not comparable due to differences in the design of the stimuli. 


\section{Conclusions}

In sum, the results of our experiments suggest that the eco-mark significantly influences how people perceive the quality of the tea and the packaging's visual appeal. Both the perceived quality and the attractiveness seem to be more influenced by the positon of the eco-mark than by its design characteristics. Thus, in the process of designing and arranging visual elements on the packaging, designers should not neglect the power of deliberate locating of the eco-mark. In this regard, future research is needed to explore the effects of various locations of the eco-mark which were not tested in our study. Furthermore, our experiments dealt only with the packaging for tea. Different food product categories should also be investigated. Finally, due to the nature of our dependent variables (subjective evaluations), the characteristics of the participants should also be taken into consideration. It would also be interesting to see if the effect of the ecomark is consistent across various groups of participants, e.g. those who are not environmentally concerned.

\section{References}

Ares, G., Besio, M., Giménez, A. \& Deliza, R. (2010) Relationship between involvement and functional milk desserts intention to purchase. Influence on attitude towards packaging characteristics. Appetite. 55, 298-304. doi: 10.1016/j.appet.2010.06.016

Ares, G. \& Deliza, R. (2010) Studying the influence of package shape and colour on consumer expectations of milk desserts using word association and conjoint analysis. Food Quality and Preference. 21 (8), 930-937. doi: 10.1016/j.foodqual.2010.03.006

Atkinson, L. \& Rosenthal, S. (2014) Signaling the green sell: The influence of eco-label source, argument specificity, and product involvement on consumer trust. Journal of Advertising. 43 (1), 33-45. doi: 10.1080/00913367.2013.834803

Banovic, M., Reinders, M. J., Claret, A., Guerrero, L. \& Krystallis, A. (2019). A cross-cultural perspective on impact of health and nutrition claims, country-of-origin and eco-label on consumer choice of new aquaculture products. Food Research International. 123, 36-47. doi: 10.1016/j.foodres.2019.04.031

Becker, L., van Rompay, T. J. L., Schifferstein, H. N. J. \& Galetzka, M. (2011) Tough package, strong taste: The influence of packaging design on taste impressions and product evaluations. Food Quality and Preference. 22 (1), 17-23. doi: 10.1016/j.foodqual.2010.06.007

Ben Youssef, A. \& Lahmandi-Ayed, R. (2008) Eco-labelling, competition and environment: Endogenization of labelling criteria. Environmental and Resource Economics. 41 (2), 133-154. doi: 10.1007/s10640-007-9184-6

Bratić, D., Miljković, P. \& Gajdek, D. (2018) Ecological symbols in green communication function on packaging. Polytechnic and Design. 6 (3), 191-198. doi: 10.19279/TVZ.PD.2018-6-3-08
Chandran, S., Batra, R. K. \& Lawrence, B. (2009) Is seeing believing? Consumer responses to opacity of product packaging. In: McGill A. L. \& Shavitt, S. (eds.) NAAdvances in Consumer Research Volume 36. Duluth, Minnesota, Association for Consumer Research, pp. 149-170. Available from: http://acrwebsite.org/ volumes/14463/volumes/v36/NA-36 [Accessed 5th October 2019]

Dantas, M. I. S., Minim, V. P. R., Deliza, R. \& Puschmann, R. (2004) The effect of packaging on the perception of minimally processed products. Journal of International Food \& Agribusiness Marketing. 16 (2), 71-83. doi: 10.1300/J047v16n02_05

De Godoy, R. C. B., Deliza, R., Gheno, L. B., Licodiedoff, S., Frizon, C. N. T., Ribani, R. H. \& dos Santos, G. G. (2013) Consumer perceptions, attitudes and acceptance of new and traditional mate tea products. Food Research International. 53 (2), 801-807. doi: 10.1016/j. foodres.2013.02.054

Delgado, C., Gómez-Rico, A. \& Guinard, J. X. (2013) Evaluating bottles and labels versus tasting the oils blind: Effects of packaging and labeling on consumer preferences, purchase intentions and expectations for extra virgin olive oil. Food Research International. 54 (2), 2112-2121. doi: 10.1016/j.foodres.2013.10.021

Dočekalová, M. \& Straková, J. (2011) The influence of eco-labelling on consumer behaviour in the Czech Republic and Slovakia. Economics \& Management. 16, 1248-1252.

Drexler, D., Fiala, J., Havlíčková, A., Potůčková, A. \& Souček, M. (2018) The effect of organic food labels on consumer attention. Journal of Food Products Marketing. 24 (4), 441-455. doi:10.1080/10454446.2 017.1311815

Erskine, C. C. \& Collins, L. (1997) Eco-labelling: Success or failure?. Environmentalist. 17 (2), 125-133. doi: 10.1023/A:1018552000651

Ertz, M., François, J. \& Durif, F. (2017) How consumers react to environmental information: An experimental study. Journal of International Consumer Marketing. 29 (3), 162-178 doi: 10.1080/08961530.2016.1273813

Esmaeili, A., Henneberry, S. \& Ebneali, S. (2013) Influence of label information on consumer acceptability of tea in Iran. Journal of Food Products Marketing. 19 (1), 15-25. doi: 10.1080/10454446.2013.739122

Faletar, I., Cerjak, M. \& Kovačić, D (2016) Determinants of attitude and buying intention of organic milk | Odrednice stava i namjere kupnje ekološkog mlijeka. Mljekarstvo. 66 (1), 59-65. doi: 10.15567/mljekarstvo.2016.0106

Fleetwood, M. D. \& Byrne, M. D. (2006) Modeling the visual search of displays: A revised ACT-R model of icon search based on eye-tracking data. Human-Computer Interaction. 21 (2), 153-197. doi: 10.1207/ s15327051hci2102_1

Germelmann, C. C. \& Held, J. (2014) Deceived or not deceived: How food consumers perceive deception. In: Cotte, J. \& Wood, S. (eds.), Advances in Consumer Research Volume 42. Duluth, Minnesota, Association for Consumer Research, pp. 313-317. Available from: http://www.acrwebsite.org/volumes/1017626/volumes/v42/NA-42 [Accessed 5th October 2019] 
Gertz, R. (2005). Eco-labelling- a case for deregulation?. Law, Probability and Risk. 4 (3), 127-141. doi: 10.1093/lpr/mgi010

Hemmerling, S., Obermowe, T., Canavari, M., Sidali, K. L., Stolz, H. \& Spiller, A. (2013) Organic food labels as a signal of sensory quality-insights from a cross-cultural consumer survey. Organic Agriculture. 3 (1), 57-69. doi: 10.1007/s13165-013-0046-y

Henderson, P. W., Giese, J. L. \& Cote, J. A. (2004) Impression management using typeface design. Journal of Marketing. 68 (4), 60-72. doi: 10.1509/ jmkg.68.4.60.42736

Hidalgo-Baz, M., Martos-Partal, M. \& González-Benito, Ó. (2017) Is advertising helpful for organic businesses? Differential effects of packaging claims. International Journal of Advertising. 36 (4), 542-561. doi: 10.1080/02650487.2016.1203857

Huang, K.-C. \& Chiu, T. (2007) Visual search performance on an LCD monitor: Effects of color combination of figure and icon background, shape of icon, and line width of icon border. Perceptual and Motor Skills. 104 (2), 562-574. doi: 10.2466/pms.104.2.562-574

Korpi, J. \& Ahonen-Rainio, P. (2015). Design Guidelines for Pictographic Symbols : Evidence from Symbols Designed by Students. In: Gartner, G. and Huang, $\mathrm{H}$. (eds.), Proceedings of the 1st ICA European Symposium on Cartography, 10-12 November 2015, Vienna, Austria. EuroCarto .pp. 1-19.

Larceneux, F., Benoit-Moreau, F. \& Renaudin, V. (2012) Why might organic labels fail to influence consumer choices? Marginal labelling and brand equity effects. Journal of Consumer Policy. 35 (1), 85-104. doi: 10.1007/s10603-011-9186-1

Lee, W. J., Shimizu, M., Kniffin, K. M. \& Wansink, B. (2013) You taste what you see: Do organic labels bias taste perceptions?. Food Quality and Preference. 29 (1), 33-39. doi: 10.1016/j.foodqual.2013.01.010

Lehto, M. R. \& Papastavrou, J. D. (1993) Models of the warning process: Important implications towards effectiveness. Safety Science. 16 (5-6), 569-595. doi: 10.1016/0925-7535(93)90024-8

Li, Y. \& Suen, C. Y. (2010) Typeface personality traits and their design characteristics. In: Proceedings of the 9th IAPR International Workshop on Document Analysis Systems, DAS '10, 9-11 June 2010, Boston, Massachusetts. New York, ACM Press. pp. 231-238. doi: 10.1145/1815330.1815360

Loebnitz, N., Schuitema, G. \& Grunert, K. G. (2015) Who buys oddly shaped food and why? Impacts of food shape abnormality and organic labeling on purchase intentions. Psychology \& Marketing. 32 (4), 408-421. doi: 10.1002/mar.20788

Magnier, L. \& Crié, D. (2015) Communicating packaging eco-friendliness. International Journal of Retail \& Distribution Management. 43 (4/5), 350-366. doi: 10.1108/IJRDM-04-2014-0048

Magnier, L. \& Schoormans, J. (2015) Consumer reactions to sustainable packaging: The interplay of visual appearance, verbal claim and environmental concern. Journal of Environmental Psychology. 44, 53-62. doi: 10.1016/j.jenvp.2015.09.005

Magnier, L., Schoormans, J. \& Mugge, R. (2016) Judging a product by its cover: Packaging sustainability and perceptions of quality in food products. Food Quality and Preference. 53, 132-142. doi: 10.1016/j.foodqual.2016.06.006

McDougall, S. J. P., de Bruijn, O. \& Curry, M. B. (2000) Exploring the effects of icon characteristics on user performance. Journal of Experimental Psychology: Applied. 6 (4), 291-306. doi: 10.1037//1076898x.6.4.291

McEachern, M. G. \& Warnaby, G. (2008) Exploring the relationship between consumer knowledge and purchase behaviour of value-based labels. International Journal of Consumer Studies. 32 (5), 414-426. doi: 10.1111/j.1470-6431.2008.00712.x

Orquin, J. L., Bagger, M. P., Lahm, E. S., Grunert, K. G. \& Scholderer, J. (2019). The visual ecology of product packaging and its effects on consumer attention. Journal of Business Research. [In Press]. doi: 10.1016/j. jbusres.2019.01.043

Pancer, E., McShane, L. \& Noseworthy, T. J. (2017) Isolated environmental cues and product efficacy penalties: The color green and eco-labels. Journal of Business Ethics. 143 (1), 159-177. doi: 10.1007/s10551-0152764-4

Piqueras-Fiszman, B. \& Spence, C. (2011) Crossmodal correspondences in product packaging. Assessing color-flavor correspondences for potato chips (crisps). Appetite. 57 (3), 753-757. doi: 10.1016/j. appet.2011.07.012

Polonsky, M. J., Carlson, L., Prothero, A. \& Kapelianis, D. (2002) A cross-cultural examination of the environmental information on packaging: Implications for advertisers. In: Taylor, C. R. (ed.) New Directions in International Advertising Research Volume 12. Bringley, United Kingdom, Emerald Group Publishing Limited, pp. 153-174. doi: 10.1016/S1474-7979(02)12025-4

Puyares, V., Ares, G. \& Carrau, F. (2010). Searching a specific bottle for Tannat wine using a check-all-that apply question and conjoint analysis. Food Quality and Preference. 21 (7), 684-691. doi: 10.1016/j.foodqual.2010.05.008

Reimann, M., Zaichkowsky, J., Neuhaus, C., Bender, T. \& Weber, B. (2010) Aesthetic package design: A behavioral, neural, and psychological investigation. Journal of Consumer Psychology. 20 (4), 431-441. doi: 10.1016/j.jcps.2010.06.009

Simmonds, G., Woods, A. \& Spence, C. (2018) "Seeing what's left": The effect of position of transparent windows on product evaluation. Foods. 7 (9), 151. doi: 10.3390/foods7090151

Sörqvist, P., Hedblom, D., Holmgren, M., Haga, A., Langeborg, L., Nöstl, A. \& Kågström, J. (2013) Who needs cream and sugar when there is eco-labeling? Taste and willingness to pay for "eco-friendly" coffee. PLoS ONE. 8 (12). doi: 10.1371/journal.pone.0080719

Suzianti, A., Rengkung, S., Nurtjahyo, B. \& Al Rasyid, H. (2015) An analysis of cognitive-based design of yogurt product packaging. International Journal of Technology. 6 (4), 659-669. doi: 10.14716/ijtech.v6i4.1105

Taufique, K. M. R., Siwar, C. \& Chamhuri, N. (2016) Factors affecting consumers' perception of eco-labels: Evidence from Malaysia. In: Wahid, A. N. M., Amaro, C. R. and Murad, W. (eds.) Proceedings of the Australia-Middle East Conference on Business and Social 
Sciences 2016, 17-18 April 2016, Dubai, United Arab Emirates. Dubai. pp. 718-748. Available from: https:// www.aabss.org.au/research-papers/factors-affecting-consumers\%E2\%80\%99-perception-eco-labels-evidence-malaysia [Accessed 5th October 2019]

Van der Laan, L. N., De Ridder, D. T. D., Viergever, M. A. \& Smeets, P. A. M. (2012) Appearance matters: Neural correlates of food choice and packaging aesthetics. PLoS ONE. 7 (7), e41738. doi: 10.1371/journal, pone.0041738

Vladić, G., Kecman, M., Kašiković, N., Pál, M. \& Stančić, M. (2016) Influence of the shape on the consumers perception of the packaging attributes. Journal of Graphic Engineering \& Design (JGED). 6 (2), 27-32. Available from: https://www.grid.uns.ac.rs/jged/ download. php?fid=158 [Accessed 5th October 2019]

Wang, E. S. T. (2013) The influence of visual packaging design on perceived food product quality, value, and brand preference. International Journal of Retail and Distribution Management. 41 (10), 805-816. doi: 10.1108/IJRDM-12-2012-0113

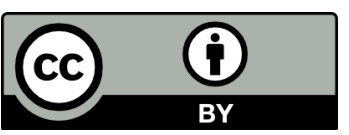

(C) 2019 Authors. Published by the University of Novi Sad, Faculty of Technical Sciences, Department of Graphic Engineering and Design. This article is an open access article distributed under the terms and conditions of the Creative Commons Attribution license 3.0 Serbia (http://creativecommons.org/licenses/by/3.0/rs/). 